\title{
CYCLEA BARBATA LEAF EXTRACT: LIPOXYGENASE INHIBITORY ACTIVITY AND PHYTOCHEMICAL SCREENING
}

\author{
NADYA FEBRI HANDAYANI, BERNA ELYA*, NURAINI PUSPITASARI \\ Department of Phytochemical and Pharmacognosy, Faculty of Pharmacy, Universitas Indonesia, Depok, 16424, Indonesia. \\ Email: berna.elya@farmasi.ui.ac.id
}

Received : June 15, 2018, Revised : September 20, 2018, and Accepted : October 25, 2018

\section{ABSTRACT}

Objective: The aim of this study was to test the anti-inflammatory activity of methanol, ethyl acetate, and n-hexane Cyclea barbata Miers. leaf extracts using a lipoxygenase inhibition method.

Methods: Enzyme activity assay was performed using colorimetric method with lipoxygenase from soybean and linoleic acid as a substrate. Absorbance was measured at $234 \mathrm{~nm}$. The total flavonoid content of the most active extract was determined using a colorimetric method with AlCl ${ }_{3}$ and phytochemical screening.

Results: The ethyl acetate extract had the highest lipoxygenase inhibiting activity, with an $\mathrm{IC}_{50}$ value of $0.267 \mu \mathrm{g} / \mathrm{mL}$. In addition, this extract had a total flavonoid content of $21.62 \mathrm{mgQE} / \mathrm{g}$ and contained flavonoids, glycosides, and terpenoids.

Conclusion: This finding indicated that $C$. barbata provides a possible anti-inflammatory effect through the inhibition of lipoxygenase. However, further research is still needed to strengthen this result.

Keywords: Anti-inflammation, Cyclea barbata Miers. leaves, Flavonoid content, Lipoxygenase, Phytochemical screening.

(C) 2018 The Authors. Published by Innovare Academic Sciences Pvt Ltd. This is an open access article under the CC BY license (http://creativecommons. org/licenses/by/4. 0/) DOI: http://dx.doi.org/10.22159/ijap.2018.v10s1.22

\section{INTRODUCTION}

Inflammation is a protective response to exogenous or endogenous stimulus that occurs to eliminate the initial cause of cell injury and to remove necrotic cells and tissues caused by cell damage [1]. The inflammatory response involves microvasculature damage, increased capillary permeability, and leukocyte migration into inflamed tissues. Localized symptoms of inflammation include redness (rubor), heat (calor), pain (dolor), and swelling (tumor).

Cyclooxygenase and lipoxygenase are enzymes that play the key roles in inflammation. Although both enzymes have the same substrate, namely arachidonic acid, each has its own metabolic pathway and products. Leukotrienes are products formed by the lipoxygenase pathway in response to immunological stimuli and non-immunological pathway [2].

The World Health Organization has stated that the use of traditional herbal medicine is very important in the maintenance of health and the prevention and treatment of diseases, especially chronic diseases [3]. One herb that has been shown empirically to have anti-inflammatory properties is Cyclea barbata Miers. C. barbata leaves are often used to treat diarrhea, abdominal pain, fever, inflammation, hypertension, and oral ulceration $[4,5]$.

According to previous research, $C$. barbata leaves contain secondary metabolites, such as flavonoids, saponins, tannins, and steroids [6,7]. In medicine, flavonoid compounds have been proven to have many benefits, including antioxidant, hepatoprotective, antibacterial, antiinflammatory, anticancer, and antiviral properties. Some flavonoids, such as hesperidin, apigenin, luteolin, quercetin, and baicalein, are reported to have anti-inflammatory and analgesic effects $[8,9]$. Flavonoids have the ability to inhibit the expression of isoforms which induce nitric oxide, cyclooxygenase, and lipoxygenase that are responsible for the production of nitrate oxide, prostanoids, leukotrienes, and other mediators of the inflammatory process, such as cytokines and chemokines. Therefore, the flavonoid compounds found in C. barbata leaves are predicted to inhibit leukotriene formation and thus have anti-inflammatory effects. Research on the ability of $C$. barbata extracts to inhibit lipoxygenase activity is still lacking. Therefore, the aim of the present study was to test the lipoxygenase inhibitory activity of methanol, ethyl acetate, and n-hexane C. barbata extracts and assay the total flavonoids and phytochemicals in the most active extract.

\section{MATERIALS AND METHODS}

\section{Materials}

C. barbata used in this study originated from Purwokerto and was obtained from the Laboratory of Pharmacognosy and Phytochemistry, Faculty of Pharmacy, Universitas Indonesia. Reference materials were baicalein (Sigma Aldrich-465 119, USA) as a standard to test the inhibitory activity of lipoxygenase, quercetin (Sigma-Aldrich-Q4951, USA) as a standard in the identification and assay of total flavonoids, beta-sitosterol (Sigma-Aldrich, USA) as a standard in the identification of terpenoids, and boldine (Sigma-Aldrich, USA) as a standard in the identification of terpenoids and alkaloids.

\section{Extract preparation}

The extract was prepared from $200 \mathrm{~g}$ C. barbata leaf powder by leveling extraction using a reflux method with a solvent ratio of 1:17. Three extracts were produced with a non-polar solvent (n-hexane), semipolar solvent (ethyl acetate), and polar solvent (methanol), respectively. The reflux time per cycle was $1 \mathrm{~h}$. This extraction was performed in triplicate. Then, each extract solution was evaporated in a vacuum rotary evaporator at $60^{\circ} \mathrm{C}$, the viscous extract was weighed, and the yield was calculated according to the following formula:

$$
\% \text { yield }=\frac{\text { Final extract weight }}{\text { Weight of powder }} \times 100
$$


Lipoxygenase activity test

First, standard solutions of baicalein and $C$. barbata extract (n-hexane, ethyl acetate, methanol, and C. barbata leaves at concentrations of 60 , $70,80,100,120$, and $140 \mu \mathrm{g} / \mathrm{mL}$ ) were prepared. The effect of baicalein on lipoxygenase activity in three extracts was assessed according to the method of Choironi (2014), with some modifications [10]. Inhibition of lipoxygenase assay is shown in Table 1.

\section{Phytochemical screening}

Phytochemical screening aimed to determine the content of the compounds contained in $C$. barbata leaf extracts with the smallest IC $_{50}$ values. Identification was performed using color reagents to test for the presence of alkaloids, flavonoids, terpenoids, tannins, saponins, anthraquinone, and glycosides.

\section{Determination of total flavonoid content}

Finally, a total flavonoid assay was conducted on the most active extract: Ethyl acetate. Total flavonoid content was measured using a colorimetric method, using aluminum chloride $\left(\mathrm{AlCl}_{3}\right)$ as a reagent. Tests were carried out to samples with or without $\mathrm{AlCl}_{3}$, and the results were compared with those of a standard solution of quercetin with or without $\mathrm{AlCl}_{3}$. The results were plotted on a graph to obtain a calibration curve for quercetin $(y=a+b x)$ which could then be used to determine the levels of flavonoids in the leaf extract. The value of $\mathrm{x}$ indicates the concentration of the sample $(\mu \mathrm{g} / \mathrm{mL})$ and y represents the absorption of the sample at $434 \mathrm{~nm}$. Then, the flavonoid levels can be calculated by dividing $\mathrm{CxDFxV}$ with mass [11]. $\mathrm{C}$ is the concentration of samples obtained from the calibration curve $(\mathrm{mg} / \mathrm{mL})$; $\mathrm{DF}$ is dilution factor; $\mathrm{V}$ is volume of stock solution (mL); $\mathrm{M}$ is mass of extract used in the test (g). Levels of total flavonoid were expressed as an equivalent of the amount of quercetin in a $1 \mathrm{~g}$ sample (QE).

\section{RESULTS}

\section{Extraction}

The yield obtained from the extraction process was $1.215 \%$ in the n-hexane extract, $1.905 \%$ in the ethyl acetate extract, and $8.365 \%$ in the methanol extract.

\section{Lipoxygenase activity test}

Preliminary test

In the preliminary test, the optimization results indicated that $\mathrm{pH} 8.5$ is the optimum condition for lipoxygenase to catalyze reaction, thus showing the highest absorption (Fig. 1).

A preliminary test of substrate concentration showed that absorption increased in line with increased linoleic acid concentrations. Significant increases occurred at the concentrations of 200 and $300 \mu \mathrm{M}$ and absorption began to decline at $400 \mu \mathrm{M}$ (Fig. 2).

\section{Inhibition of lipoxygenase activity by baicalein and extracts}

The $\mathrm{IC}_{50}$ value obtained for baicalein was $0.153 \mathrm{mg} / \mathrm{mL}$ (Fig. 3a). Lipoxygenase activity assay was performed using three extracts at a concentration of $100 \mathrm{mg} / \mathrm{mL}$. Ethyl acetate extract had the highest percent inhibition, amounting to $53.76 \%$, so that $\mathrm{IC}_{50}$ values obtained ethyl acetate extract of C. barbata leaf are $0.267 \mathrm{mg} / \mathrm{mL}$ (Fig. 3b).

\section{Phytochemical screening}

Ethyl acetate extract of $C$. barbata leaves contained flavonoids, glycosides, and terpenoids.

\section{Total flavonoid content}

Based on calculation as described before, $1 \mathrm{~g}$ of the ethyl acetate extract contains $21.62 \mathrm{mg}$ of quercetin equivalents.

\section{DISCUSSION}

Lipoxygenase activity

Preliminary test

A preliminary test was carried out to obtain the optimum conditions for enzyme activity, including $\mathrm{pH}$, temperature, and concentration of the substrate [2]. Large changes in $\mathrm{pH}$ can alter the enzyme active site as well as the enzyme formation such that the bond between enzyme and substrate will be broken, which causes the reaction to slow down or cease altogether. In some cases, it can cause enzyme denaturation [2]. $\mathrm{pH}$ optimization is, therefore, important before testing and storage of an enzyme. Our optimization results showed that $\mathrm{pH} 8.5$ provided optimum results, i.e., caused the linoleic

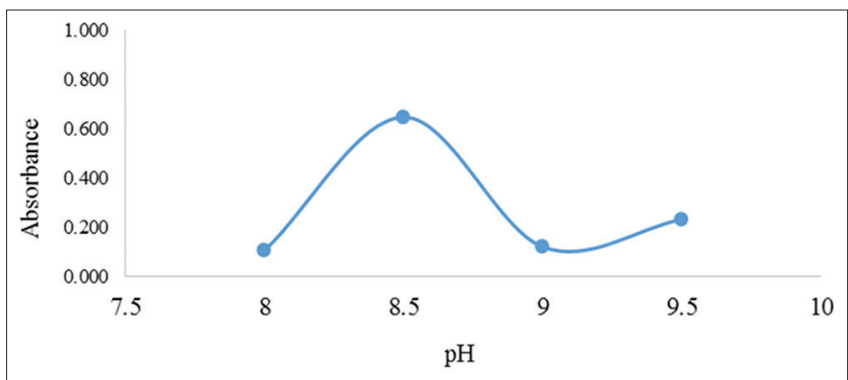

Fig. 1: Optimization of $\mathrm{pH}$ condition

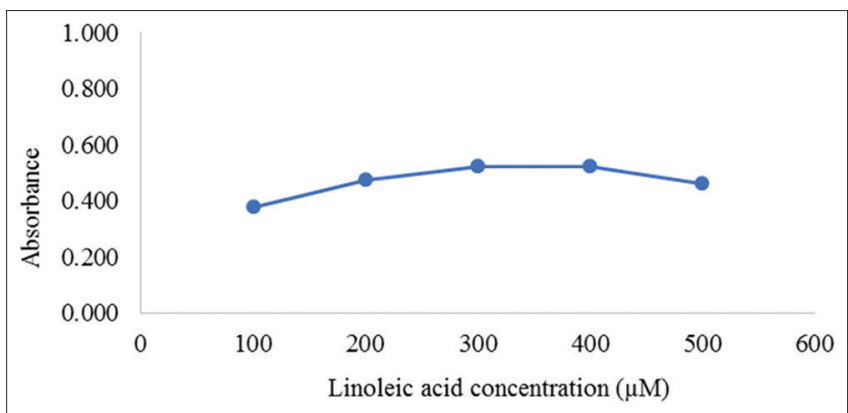

Fig. 2: Optimization of substrate concentration linoleic acid

Table 1: Inhibition of lipoxygenase assay in a baicalein (as positive control) and sample extract

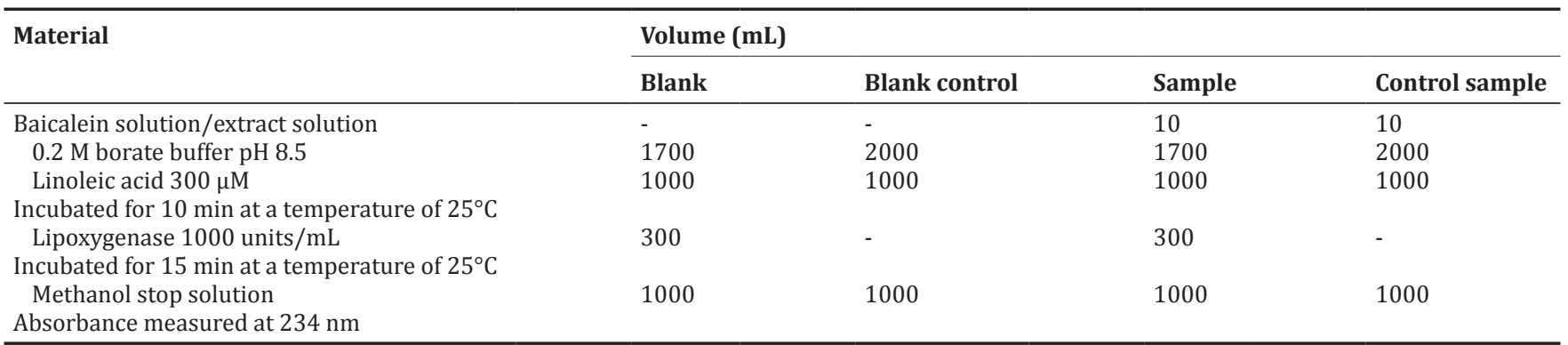




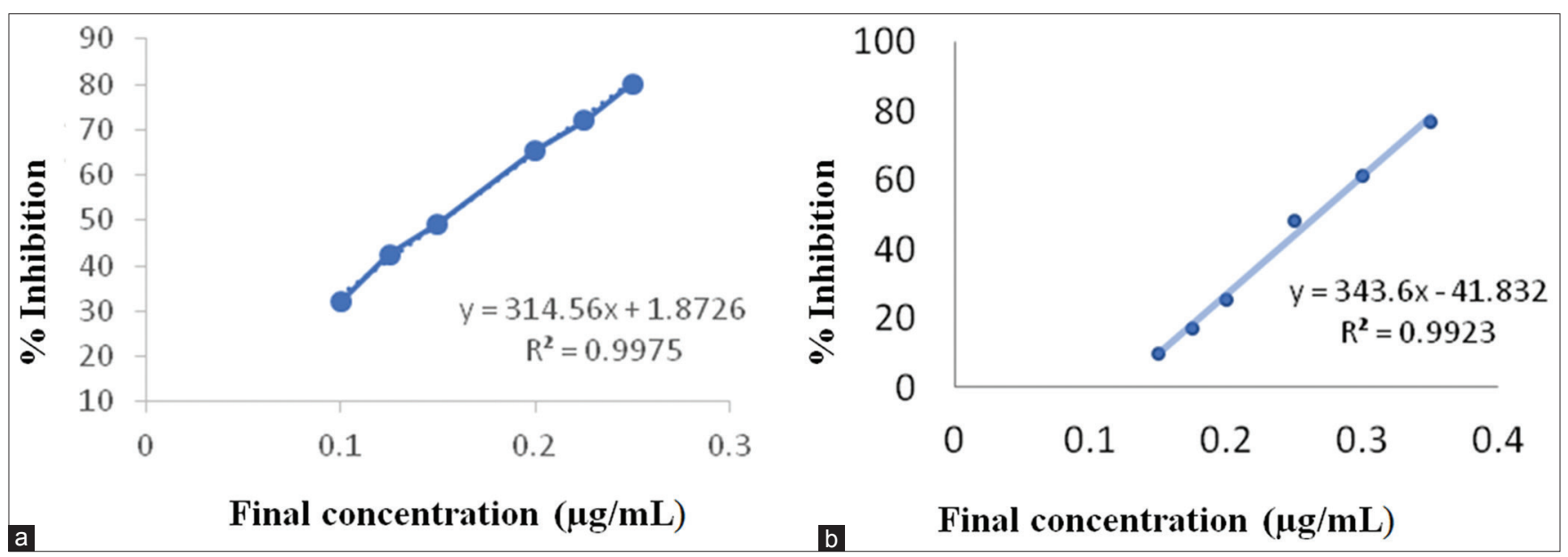

Fig. 3: ( $a$ and b) Calibration curves and effect of baicalein and ethyl acetate on lipoxygenase activity

acid substrate and lipoxygenase enzymes to produce the highest absorption (Fig. 1).

The concentration of linoleic acid substrate was also optimized. Various concentrations were tested: $100,200,300,400$, and $500 \mu \mathrm{M}$ (final concentrations $25,50,75,100$, and $125 \mu \mathrm{M}$ ). Selection of the substrate concentration was based on previous research. The absorption of linoleic acid increased in line with increased linoleic acid concentrations (Fig. 2). Significant increases occurred at concentrations of $200 \mu \mathrm{M}$ and $300 \mu \mathrm{M}$ and absorption began to decline at $400 \mu \mathrm{M}$ because the enzyme active sites were then filled with substrate so that there was no free enzyme remaining to form additional complexes. Therefore, further increases in linoleic acid concentration will neither increase the reaction rate nor significantly affect absorption [2]. Thus, it can be concluded that the optimum substrate concentration is $300 \mu \mathrm{M}$ (final concentration $75 \mu \mathrm{M}$ )

Lipoxygenase concentrations were also optimized. Various enzyme concentrations were tested: 400, 800, and 1000 units $/ \mathrm{mL}$ (final concentrations 30,60 , and 75 units $/ \mathrm{mL}$ ). The enzyme reaction rate is directly proportional to the concentration of the enzyme: The higher the concentration of enzyme, the faster the reaction and the higher the resulting absorption, because when more enzyme active sites are present, more substrate can bind to the enzyme and form a complex. An increased absorption indicates that more products were produced [15]. The enzyme used in this assay is 1000 units $/ \mathrm{mL}$. Selection of a concentration of 1000 units/mL is also supported by data from a previous study $[12,13,14,16,17]$.

Optimization of the stop methanol solution was performed to ensure that the reaction between linoleic acid and lipoxygenase was completely stopped on addition of methanol. Various incubation times were tested: 0,5 , and $10 \mathrm{~min}$. No significant changes in absorption were noted with variations in incubation time. At $0 \mathrm{~min}$, absorption was measured at 0.249; at $5 \mathrm{~min}$, absorbance was measured at 0.240 ; and at $10 \mathrm{~min}$, absorption was measured at 0.228 . This indicates that methanol is effective in stopping the lipoxygenase reaction. Researchers used methanol in stop solutions in similar experiments in a previous study $[13,14,20,21]$.

\section{Inhibition of lipoxygenase activity by baicalein}

Baicalein is a natural flavonoid derived from Scutellaria baicalensis roots. It is a lipoxygenase inhibitor that possesses a catechol group that chokes the iron on the lipoxygenase and reduces its active site, preventing the substrate and enzyme from reacting [9]. The $\mathrm{IC}_{50}$ value obtained for baicalein in the present study was $0.153 \mu \mathrm{g} / \mathrm{mL}$ (Fig. 3a), whereas it was 0.237 in a previous study [14]. Different IC $_{50}$ results can occur due to differences in measurement conditions, such as temperature, incubation time, and instruments used.
In the lipoxygenase inhibition test, it was found that the ethyl acetate extract had the highest percentage inhibition $(53.76 \%)$, so $\mathrm{IC}_{50}$ values were obtained for the ethyl acetate extract $(0.267 \mu \mathrm{g} / \mathrm{mL}$; Fig. $3 \mathrm{~b})$. When compared to the positive control, baicalein was shown to have an $\mathrm{IC}_{50}$ value lower than that of the ethyl acetate extract. This shows that baicalein is more able to inhibit the formation of lipoxygenase products with a linoleic acid substrate.

Based on previous research, the C. barbata ethyl acetate extract contains some secondary metabolites, such as flavonoids, glycosides, and terpenoids [6,7]. Flavonoid compounds are able to inhibit lipoxygenase activity by donating electrons from their $\mathrm{OH}$ groups to reduce the active site of the lipoxygenase so that the bond between the lipoxygenase substrate is being weakened [18]. Flavonoids, glycosides, and terpenoids in the $C$. barbata ethyl acetate extract also have very important roles in the inhibition of lipoxygenase activity [19].

\section{Phytochemical screening}

Phytochemical screening was performed on the most active extract, the ethyl acetate extract, which was shown to contain flavonoids, glycosides, and terpenoids.

\section{Determination of total flavonoid content}

The extract used for this test was ethyl acetate as it was shown to be the most active of all extracts produced in the present study. Determination of total flavonoid content was done by colorimetric methods using $\mathrm{AlCl}_{3}$ and quercetin as a standard. Standard solution of quercetin measured with various concentrations of 3.03, 4.04, 5.05, 6.06, 7.07, and $8.08 \mu \mathrm{g} / \mathrm{mL}$ measured at a wavelength of $434 \mathrm{~nm}$. Absorbance values of the ethyl acetate extract quercetin plotted against a standard curve which has been obtained and calculated the total flavonoid content. The content of total flavonoids of ethyl acetate extract is $21.62 \mathrm{mg} \mathrm{QE} / \mathrm{g}$.

\section{CONCLUSION}

Ethyl acetate extracts of $C$. barbata leaves have the highest lipoxygenase inhibitory activity of all extracts tested with an $\mathrm{IC}_{50}$ of $0.267 \mu \mathrm{g} / \mathrm{mL}$. Secondary metabolites contained in the ethyl acetate extract were flavonoids, glycosides, and terpenoids. The level of flavonoids in the ethyl acetate extract was $21.62 \mathrm{mgQE} / \mathrm{g}$. This finding indicated that $C$. barbata provides a possible anti-inflammatory effect through inhibition of lipoxygenase. However, further research is still needed to strengthen this result.

\section{ACKNOWLEDGMENTS}

The authors would like to express gratitude and appreciation to Universitas Indonesia for financing this study through PITTA Research Grants Universitas Indonesia 2017. 


\section{CONFLICTS OF INTEREST}

Authors declare no conflicts of interest in this research.

\section{REFERENCES}

1. Kumar V, Abbas A, Aster J, Robbins S, Cornain S, Nasar I. Robbins Pathology Textbook. Jakarta: Book Medical Publishers EGC; 2007.

2. Murray R, Granner D, Rodwell V. Biochemistry Harper. $27^{\text {th }}$ ed. Jakarta: EGC Book Medical Publishers; 2006.

3. World Health Organization. WHO Traditional Medicine Strategy 20142023. Geneva: World Health Organization; 2013.

4. Perta, R. Benefits cincau and cincau manufacturing base in region Koto Baru. Jurnal Nasional Ecopedon JNEP 2016;1:84-7.

5. Kusmardiyani S, Insanu M, Asyhar M. Effect of glycosidic flavonols isolated from green grass jelly (Cyclea barbata Miers) leaves. Procedia Chem 2014;13:194-7.

6. Farida YG. Toxicity test leaf extract and fraction in cincau black (dazzling B. palustris) and cincau leaf green (Cyclea barbata L. Miers). J Bahan Alam Indones 2012;2:1-6.

7. Kumar S, Pandey AK. Chemistry and biological activities of flavonoids: An overview. ScientificWorldJournal 2013;2013:162750.

8. Deschamps JD, Kenyon VA, Holman TR. Baicalein is a potent in vitro inhibitor against both reticulocyte 15-human and platelet 12-human lipoxygenases. Bioorg Med Chem 2006;14:4295-301.

9. Choironi NA. Activity Inhibition of Lipoxygenase (LOX) by Tribe Zingiberaceae Plant Extracts and Isolation of Selected Plant Secondary Metabolites. Thesis of Pharmacy. Bandung Institute of Technology: Unpublished; 2014.

10. Bhaigyabati T, Devi P, Bag G. Assessment of total flavonoids content and antioxidant activity of aqueous extract of rhizome three Hedychium species of Manipur Valley. Int J Pharm Sci Rev Res 2014;30:154-9.

11. Nabilah, Elya B, Djajadisastra J. Lipoxygenase inhibitory assay of Averrhoa carambola L. leaves extract. Int J Chem Tech Res 2017;10:342-7.

12. Prakash H, Shailasree S, Sampath-Kumara K, Niranjana S. In vitro antioxidant activity, lipoxygenase, cyclooxygenase-2 inhibition and DNA protection properties of Memecylon species. Int J Pharm Pharm Sci 2013;5:257-62.

13. Putri N, Elya B, Puspitasari N. Antioxidant activity and lipoxygenase inhibition test with total flavonoids content from Garcinia kydia Roxburgh leaves extract. Pharmacog J 2017;9:280-4

14. Puri D. Textbook of Medical Biochemistry. $3^{\text {rd }}$ ed. India: Elsevier; 2011.

15. Bisswanger H. Enzyme assays. Perspect Sci 2014;1:41-55.

16. Kumazawa S, Suzuki S, Ahn M, Kamihira M, Udagawa Y, Bang K, et al. A new chalcone from propolis collected on Jeju Island, Korea. Food Sci Technol Res 2006;12:67-9.

17. Chedea VS, Jisaka M. Inhibition of soybean lipoxygenases-structural and activity models for the lipoxygenase isoenzymes family. In: Recent Trends for Enhancing the Diversity and Quality of Soybean Products. Rijeka, Croatia: InTech; 2011. p. 113-5.

18. Paguigan N, Chichioco-Hernandez C. 15-Lipoxygenase inhibition of selected Philippine medicinal plants. PHCOG J 2014;6:43-6.

19. Sauriasari R, Azizah N, Basah K. Tyrosinase inhibition, 2,2-diphenyl1-picrylhydrazyl radical scavenging activity, and phytochemical screening of fractions and ethanol extract from leaves and stem bark of matoa (Pometia pinnata). Asian J Pharm Clin Res 2017;10:85-9.

20. Elya B, Puspitasari N, Sudarmin AC. antioxidant activity and inhibition of lipoxygenase activity ethanol extract of endosperm Arenga pinnata (wurmb) Merr. Asian J Pharm Clin Res 2017;10:76-80.

21. Avelia S, Mauldina MG, Elya B. Antioxidant activity and lipoxygenase inhibitory assay with total flavonoid content of Garcinia lateriflora Blume leaves extract. Asian J Pharm Clin Res 2017;10:163-5. 